\title{
NATURAL ANTIOXIDANTS AS DEFENSE SYSTEM AGAINST CANCER
}

\author{
ANTERPREET CHAHAL ${ }^{1}$, ADESH K SAINI ${ }^{1}$, ANIL KUMAR CHHILLAR ${ }^{2}$, REENA V SAINI ${ }^{1 *}$ \\ ${ }^{1}$ Department of School of Biotechnology, Faculty of Applied Sciences and Biotechnology, Shoolini University of Biotechnology and \\ Management Sciences, Bajhol, Solan - 173 229, Himachal Pradesh, India. ${ }^{2}$ Centre for Biotechnology, MD University, Rohtak - 124 001, \\ Haryana, India. Email: reenasaini@shooliniuniversity.com
}

Received: 05 December 2017, Revised and Accepted: 17 January 2018

ABSTRACT

In living cells, the production of free radicals that comprise both reactive oxygen species (ROS) and reactive nitrogen species is highly regulated that help the cells to sustain redox homeostasis. Overproduction of ROS from mitochondrial electron transport chain leakage or excessive stimulation of xanthine oxidase and other oxidative enzymes leads to the uncontrolled production of free radicals leading to oxidative stress that can mediate damage to cell structures. This damage can be repaired by the antioxidant defense system. Antioxidants are capable of stabilizing, or deactivating, free radicals before they attack cellular components such as DNA, proteins, and lipids. The use of antioxidants in cancer prevention is a rapidly evolving research area where antioxidants scavenge free radicals and thus, indirectly help in the prevention of cancer. A wide range of antioxidants such as glutathione, N-acetylcysteine, coenzyme Q10, lycopene, flavonoids, and isoflavones when used in combination with chemotherapy and radiotherapy, result in the reduction of drug toxicity and enhanced efficacy of anticancer agents. This review aims at the use of these exogenous antioxidants as disease-oriented therapy and elucidating the relation of antioxidant enzymes with different types of cancers to overcome the harmful effects of cancer treatment.

Keywords: Antioxidants, Cancer, Reactive oxygen species, Glutathione, Flavonoids, Tumor.

(C) 2018 The Authors. Published by Innovare Academic Sciences Pvt Ltd. This is an open access article under the CC BY license (http://creativecommons. org/licenses/by/4. 0/) DOI: http://dx.doi.org/10.22159/ajpcr.2018.v11i5.24119

\section{INTRODUCTION}

Free radicals are unstable molecules that are formed as natural byproducts in the body during biological processes and lead to oxidative stress. This imbalance is repaired by the body's endogenous antioxidant defense system and by ingesting exogenous antioxidants [1]. In living cells, free radicals that comprise both reactive oxygen species (ROS) and reactive nitrogen species (RNS) are produced in a regulatory manner that helps to sustain redox homeostasis at the cellular level in the normal healthy tissues [2]. ROS and RNS, which are together referred as ROS and RNS have an important role in gene regulation through signaling mechanisms $[3,4]$.

Most cells can produce superoxide $\left(\mathrm{O}_{2}{ }^{-}-\right)$, hydrogen peroxide $\left(\mathrm{H}_{2} \mathrm{O}_{2}\right)$, and nitric oxide (NO) on demand and these free radicals play a key role in cellular processes as in the generation of adenosine triphosphate (ATP) during oxidative phosphorylation [5]; detoxification of xenobiotics by cytochrome P450 [6]; apoptosis of defective cells, killing microorganisms, and cancer cells by macrophages and cytotoxic lymphocytes $[7,8]$. Overproduction of ROS from mitochondrial electron transport chain leakage or excessive stimulation of xanthine oxidase and other oxidative enzymes leads to uncontrolled production of free radicals leading to oxidative stress that can mediate damage to cell structures, including lipids and membranes, proteins, and nucleic acids and form harmful products such as lipid peroxides and other lipid adducts. The consequent protein damage results in loss of enzyme activity, while DNA damage can result in mutagenesis and carcinogenesis [9-11]. These consequences, thus, make free radicals responsible for causing several human diseases $[12,13]$. Excess of free radicals are scavenged endogenously by enzymatic antioxidants such as superoxide dismutase (SOD), catalase (CAT), glutathione peroxidase (GPx), thioredoxin reductase [14-16], and non-enzymatic antioxidants such as uric acid, Vitamin A (retinoids), carotenoids, alpha-tocopherol (Vitamin-E), flavonoids, and other related polyphenols such as quercetin, catechins, isoflavones, lignans, flavanones, and ellagic acid $[17,18]$.
Antioxidants act as a radical scavenger, hydrogen donor, electron donor, peroxide decomposer, singlet oxygen quencher, enzyme inhibitor, synergist, and metal-chelating agents. Both enzymatic and non-enzymatic antioxidants exist in the intracellular and extracellular environment to detoxify ROS [19]. Supplementation of antioxidants in cancer treatment is a rapidly evolving area as they have been widely studied for their ability to prevent cancer in humans and decreasing side effects of existing cancer treatments including chemotherapy and radiotherapy $[20,21]$.

\section{ROS AND RNS}

ROS is a broader term; it includes many reactive species, e.g.,superoxide $\left(\mathrm{O}_{2}{ }^{\circ}\right)$, hydroxyl $\left(\mathrm{OH}^{\circ}\right)$, peroxyl $\left(\mathrm{ROO}^{\circ}\right)$, alkyl radical, alkoxyl (RO') radicals, singlet oxygen $(\mathrm{O})$ and semiquinone radical $\left(\mathrm{HQ}^{\circ}\right)$, and ozone $\left(\mathrm{O}_{3}\right)$ [22]. There are two types of ROS, (a) which contain one or more unpaired electron(s) in their outer molecular orbitals, for example, superoxide, nitric oxide and hydroxyl radicals, and (b) non-radical ROS, which include hydrogen peroxide, ozone, peroxynitrate and hydroxide that do not have unpaired electron(s) but are chemically reactive and can be converted to radical ROS [23]. Hydroxyl radicals are formed in the presence of metals and hydrogen peroxide (Fenton reaction); peroxynitrite might play a small role in hydroxyl radical formation. In this process, certain non-radicals are also produced that are either oxidizing agents or easily converted into radicals, such as $\mathrm{HOCl}$ (hypochlorous acid), ozone, $\mathrm{H}_{2} \mathrm{O}_{2}$, and lipid peroxides with no unpaired electrons. $\mathrm{H}_{2} \mathrm{O}_{2}$ and lipid peroxides also serve as a source of highly reactive ${ }^{\circ} \mathrm{OH}, \mathrm{ROO}^{\circ}$, and $\mathrm{RO}^{*}$ radicals. The $\mathrm{O}_{2}{ }^{\circ}$ - reacts quickly with very few molecules, whereas hydroxyl radical $\mathrm{OH}^{\bullet}$ has an extremely high rate of reactivity [22]. Superoxide anion can be generated both enzymatically, e.g., during the NADPH phagocytes oxidase reaction in neutrophils, and non-enzymatically in the mitochondrial respiratory chain. The superoxide anion plays an important role in the formation of other ROS such as hydrogen peroxide, hydroxyl radical, or singlet oxygen in living systems [24]. 
RNS is a collective term that includes nitric oxide radical ( $\mathrm{NO}^{\circ}$ ), peroxynitrite (ONOO-), nitrogen dioxide radical $\left(\mathrm{NO}_{2}{ }^{-}\right)$, and other oxides of nitrogen and products arising when $\mathrm{NO}^{*}$ reacts with $\mathrm{O}_{2}^{-}-$, RO', $\mathrm{H}^{*} \mathrm{NO}^{*}$ (HNO, Reduced form of nitric oxide; $\mathrm{HNO}_{2-}$, nitrous acid) [25]. The superoxide anion can react with nitric oxide ( $\mathrm{NO}^{\circ}$ ) and form peroxynitrite (ONOO-), which can generate toxic compounds such as hydroxyl radical and nitric dioxide [26]. NO` plays a major role in cellular signaling, vasodilation, insulin secretion, peristalsis, neural development, and immune response [27]. It is a highly reactive small uncharged molecule containing one unpaired electron, therefore, considered a free radical. Endogenous $\mathrm{NO}^{*}$ is formed in the biological tissues through the action of nitric oxide synthase where L-arginine and oxygen are converted into $\mathrm{NO}^{*}$ and citrulline through a fiveelectron oxidative process. The reaction requires the presence of many cofactors such as flavin adenine dinucleotide, flavin mononucleotide, nicotinamide adenine dinucleotide phosphate, tetrahydrobiopterin, and heme $[28,29]$. L-arginine gets converted into L-citrulline and nitric oxide by the action of NOS, but under uncoupling conditions, these enzymes also produce superoxide. Unregulated production of nitric oxide can be damaging to tissues due to its potential cytotoxicity [30].

Under steady state conditions, the ROS molecules are scavenged by various antioxidative defense mechanisms [31]. Enhanced generation of ROS can overcome cell's intrinsic antioxidant defenses resulting in a condition known as "oxidative stress." The equilibrium between the production and the scavenging of ROS may be agitated by various biotic and abiotic stress factors [32]. Excessive or sustained ROS production, when exceeding the available antioxidant defense systems, produces oxidative stress, (Fig. 1) that damages cell structure and disrupts function through lipid peroxidation of cell membranes and degrades nucleic acids [33].

Oxidative damage to cells and tissues also leads to aging and other chronic diseases such as atherosclerosis, heart failure, and cancer [34]. Humans are exposed to many anthropogenic factors like toxic metals (lead, cadmium, mercury, and arsenic) that are widely found in our environment including contaminated air, water, soil, and food. Exposure to arsenic increases free radical generation and cause damage to the biological membrane through increased lipid peroxidation and protein carbonyl content followed by decreased antioxidant defense system [35,36]. Glutathione (GSH) is an important biomolecule involved in the antioxidant defense system against toxicants and arsenic showed high affinity toward GSH leading to decreased levels of GSH [37]. Chronic arsenic exposure has been associated with apoptosis of lymphocytes and involved in immunotoxic responses [38]. It has been reported that arsenic exposure causes increased generation of free radicals coupled with enhanced oxidative stress leading to thymic atrophy in a mouse model $[37,39]$.

Recent studies indicate that transition metals act as catalysts in the oxidative reactions of biological macromolecules; therefore, the toxicities associated with these metals might be due to oxidative tissue damage [40]. Redox-active metals, such as iron, copper, and chromium, undergo redox cycling whereas redox-inactive metals, such as lead, cadmium, mercury, and other metals deplete the major antioxidants, particularly thiol-containing antioxidants and enzymes of the cell [36].

\section{ANTIOXIDANT DEFENSES}

Antioxidants act as a radical scavenger, hydrogen donor, electron donor, peroxide decomposer, singlet oxygen quencher, enzyme inhibitor, synergist, and metal-chelating agents. Both enzymatic and non-enzymatic antioxidants exist in the intracellular and extracellular environment to detoxify ROS. Endogenous antioxidants play a crucial role in maintaining optimal cellular functions and thus, systemic health and well-being. However, under conditions, which promote oxidative stress, endogenous antioxidants may not be sufficient and dietary antioxidants may be required to maintain optimal cellular functions [19].
Two principal mechanisms of action have been proposed for antioxidants [41]. The first is a chain breaking mechanism by which the primary antioxidant donates an electron to the free radical present in the system. The second mechanism involves removal of ROS/RNS initiators (secondary antioxidants) by quenching chain initiating catalyst. Antioxidants may exert their effect on biological systems by different mechanisms, including electron donation, metal ion chelation, or by gene expression regulation [42].

Many antioxidants have aromatic ring structures and are able to delocalize the unpaired electrons. Antioxidant mechanisms of polyphenolic compounds are based on hydrogen donation abilities and chelating metal ions [33]. After donating a hydrogen atom, phenolic compounds become resonance-stabilized radicals, which do not easily participate in other radical reactions.

Endogenous protein antioxidants with enzymatic activity such as GPx, SOD, and CAT also play a critical role in reduction of oxidative stress [43]. GPx exist in two forms: Selenium-dependent and selenium independent, each with different subunits and different active sites $[44,45]$. GPx catalyzes the reduction of $\mathrm{H}_{2} \mathrm{O}_{2}$ or organic peroxide (ROOH) to water or alcohol $[46,47]$; this process occurs in the presence of GSH, which is converted into GSSG (oxidized glutathione) during this reaction. The reaction has special significance in the protection of the polyunsaturated fatty acids located within the cell membranes where the enzyme functions as a part of a multi-component antioxidant defense system within the cell [48]. There are four isoforms in humans, cytosolic and mitochondrial (GPx1), cytosolic (GPx2), extracellular (GPx3), and the phospholipid peroxide (GPx4) [49,50]. The kidney and liver have the highest amount of GPx [51]. GPx enzyme plays an important role as a first line of defense against oxidative stress as it is the first enzyme that is activated under high levels of ROS in various body parts and tissues including dorsal root ganglion $[52,53]$. Recent studies have shown the involvement of GPx4 in an endogenous tumor suppressive mechanism known as ferroptosis which can be triggered by small molecules or conditions inhibiting the biosynthesis of glutathione or GPx4 $[54,55]$. Cells tend to be indefatigably exposed to the threat of ROS-mediated destruction, as inhibition of GPx4 activity leads to the rapid accumulation of L-ROS and cell death in cell culture, and deletion of Gpx4 in mice is embryonic lethal [56,57]. RSL3 (RASselective lethal 3, Type II) mediated inactivation of GPx4 is essential to induce ferroptosis and overexpression of $\mathrm{GP} \times 4$ blocks RSL3-induced cell death [56].

SODs are a group of key enzymes functioning as the first line of antioxidant defense with the ability to convert highly reactive superoxide radicals into hydrogen peroxide and molecular oxygen [58]. There are four isozymes of SOD: (1) SOD1 (associated with $\mathrm{Cu} / \mathrm{Zn}$ ) requires $\mathrm{Cu}$ and $\mathrm{Zn}$ for its biological activity; the loss of $\mathrm{Cu}$ results in its complete inactivation and is the cause of multiple diseases in human and animals [59]. (2) SOD2, it has been shown to be involved in inflammatory response [60-62]. The SOD3 enzyme has many physiological effects; studies have reported reduced cardiovascular damage by administration of recombinant SOD3 [63,64]. The SOD4 associated with $\mathrm{Ni}$ was discovered in Streptomyces [65] but has also been found in some genera of actinobacteria and cyanobacteria [66]

Catalase is a tetrameric porphyrin containing an enzyme that is located mainly in peroxisomes. It catalyzes the conversion of $\mathrm{H}_{2} \mathrm{O}_{2}$ to water and molecular oxygen [47]. Catalase along with other enzymes such as GPx and SOD have been considered as biomarkers of oxidative stress in various organs; for example, in streptozotocin-induced diabetic rats, hepatic levels of these enzymes are dramatically reduced, although treatment with red palm oil (Elaeis guineensis) and Rooibos tea extract (Aspalathus linearis) can improve this effect [67-69].

Another major thiol antioxidant is the tripeptide GSH, a multifunctional intracellular antioxidant which is considered as the major thioldisulfide redox buffer of the cell [70]. Free form of this antioxidant 
is present mainly in reduced form (GSH), which is converted into its oxidized form (GSSG) by enzyme glutathione reductase [71,72]. The main protective roles of glutathione against oxidative stress are that it can act as a cofactor for several detoxifying enzymes, participate in amino acid transport across the plasma membrane, scavenge hydroxyl radical and singlet oxygen directly, and regenerate Vitamins $\mathrm{C}$ and $\mathrm{E}$ back to their active forms [70].

\section{FREE RADICALS AND CANCER}

The major targeting site of free radicals is genetic material carried by the cells. The types of damages include strand breaks (single or double strand breaks), various forms of base damage yielding products such as 8-hydroxyguanosine, thymine glycol or abasic sites, damage to deoxyribose sugar as well as DNA protein cross-linkages [73]. These damages can result in inheritable mutations that can yield a cancer in somatic cells or fetal malformations in the germ cells. The involvement of free radicals with tumor suppressor genes and proto-oncogenes recommend their role in the development of different human cancers [74]. Constant activation of transcription factors such as NF$\kappa \mathrm{B}$ (nuclear factor kappa-light-chain-enhancer of activated B-cells) and activator protein-1 appears to be one functional role of elevated ROS levels during tumor progression [75].

Compared with normal cells, malignant cells seem to function with higher levels of endogenous oxidative stress in culture and in vivo $[76,77]$. For example, leukemia cells freshly isolated from blood samples from patients with chronic lymphocytic leukemia or hairy-cell leukemia showed increased ROS production compared with normal lymphocytes. It has been shown that ROS have toxic effects to both normal and abnormal cells (infected by intracellular pathogens and malignant cells). It has been shown that increased oxidative stress could enhance prevalence of malignancies by direct cellular damage, [78-80] however, oxidative stress when applied as immune system arms could protect organisms from invading pathogens and malignant cells [81].

Although the precise pathways leading to ROS stress in cancer cells remain unclear, several intrinsic and extrinsic mechanisms are thought to cause oxidative stress during cancer development and disease progression. Activation of oncogenes, anomalous metabolism, mitochondrial dysfunction and loss of functional p53 are some of the intrinsic factors known to cause increased ROS production in cancer cells [82-85]. Mitochondrial DNA (mt-DNA) mutations have also been shown to be correlated with increased ROS levels in certain types of cancer cells, including those in solid tumors and leukemia $[15,16]$. Several protein components of the electron transport chain are encoded by mt-DNA. Thus, mutations of mt-DNA are likely to cause impairments in electron transfer, leading to leakage of electrons and the generation of superoxide, which can subsequently be converted to other types of ROS [84].

At an advanced disease stage, cancer cells usually exhibit genetic instability and show a significant increase in ROS generation, that results in gene mutations induced by ROS (especially in the mitochondrial genome) leading to further metabolic malfunctions and abnormal ROS generation. Increased ROS stress in cancer cells correlates with the aggressiveness of tumors and poor prognosis. Normal ROS levels are necessary for the progression of several basic biological processes including cellular proliferation and differentiation [86]. Cancer cells have an intrinsic elevated ROS level compared to normal body cells. Therefore, elevated oxidative signaling may be implicated in the promotion and progression of a number of different cancers. ROS can affect cellular proteins, lipids, and DNA, leading to genomic instability and activation of various signaling cascades related to tumorigenesis (Fig. 2). The formation of new blood vessels out of pre-existing capillaries, referred to as angiogenesis, is an essential component of tumor growth, survival, and metastasis [87,88]. Proliferation, migration, and tube formation in endothelial cells are some of the key events in tumor angiogenesis which are mediated by ROS [88]. As cancer cells exhibit a greater ROS levels than normal cells, so these ROS

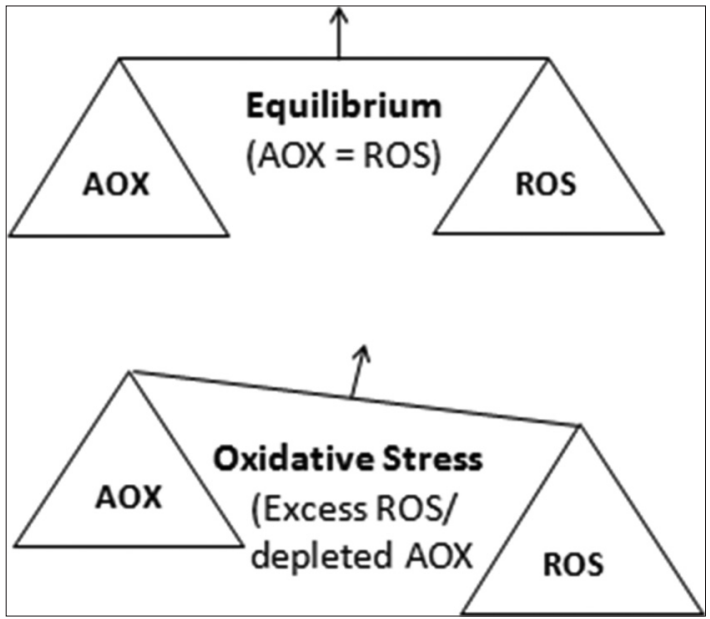

Fig. 1: Disturbance in the equilibrium between ROS and antioxidants leads to Oxidative stress

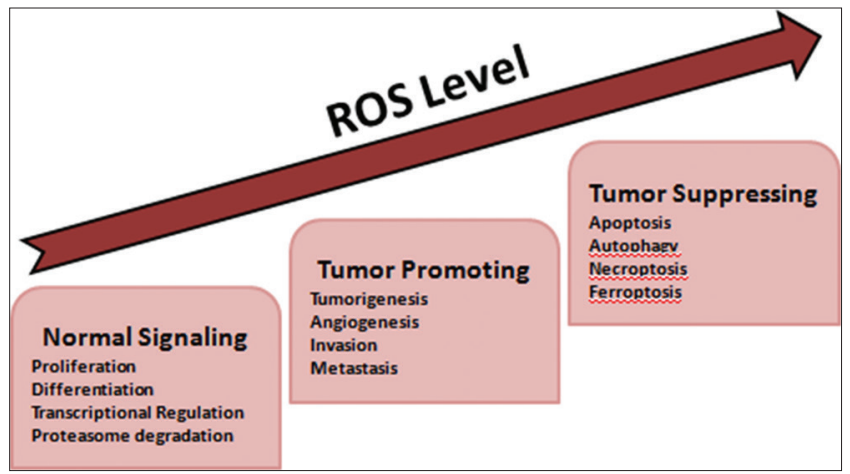

Fig. 2: Elevated ROS levels have been linked to various tumorigenic processes which leads to biochemical and molecular changes.

levels are counteracted by an increased activity of antioxidant enzymes in cancer cells which leads to activation of different cell death pathways, therefore, limiting the cancer progression [86].

\section{ANTIOXIDANTS AGAINST CANCER}

Cancer is a growing health problem in both developing and developed countries. At present, the on-going treatments for cancer are chemotherapy, radiotherapy, and surgery. Some of the most used chemotherapy drugs include antimetabolites (e.g., methotrexate), DNA interactive agents (e.g., cisplatin and doxorubicin), anti-tubulin agents (taxanes), hormones, and molecular targeting agents $[89,90]$. However, clinical uses of these drugs are accompanied with several side effects such as hair loss, suppression of bone marrow, drug resistance, gastrointestinal lesions, neurologic dysfunction, and cardiac toxicity $[91,92]$. Therefore, there is a need for new anticancer agents with better effectiveness and lesser side effects.

Endogenous antioxidant enzymes like SOD that provide the first line of defense in human cancers have been studied in human cancers. In human patient samples, Cu-Zn SOD activity is decreased in breast carcinoma [93]. In human esophageal cancers, studies have shown that decreased Mn-SOD levels are associated with increased incidences of esophageal adenocarcinoma [94]. In human oral cancers, a high expression level of Mn-SOD was associated with better disease-specific survival, especially for patients with moderate or poor differentiation of squamous cells of buccal cavity, and early stage buccal mucosal squamous cell carcinomas [95].

Catalase enzyme has also been studied for its role in cancer disease. Decreased catalase activity due to the inflammation in lung leads to increase hydrogen peroxide intracellularly and create an intracellular 
environment favorable to DNA damage and the promotion of cancer [96]. Another study showed higher oxygen-free radical production and decreased catalase activity, supporting the oxidative stress in breast cancer [97].

Loss of heterozygosity of cytosolic GPx1 gene was implicated in lung cancer patients by Moscow et al. [98]. Ratnasinghe et al. investigated the association between the proline to leucine polymorphism at codon 198 of hGPx1 (human cellular GPx1) and lung cancer risk. They showed that due to the high prevalence of leucine residue, the hGPx1 variant contributes significantly to lung cancer risk among the Caucasians but not among the ethnic Chinese who do not exhibit this polymorphism [99].

There are other non-enzymatic antioxidants with beneficial effects in medical practice, especially in cancer [100]. One of them is quercetin, a plant-derived aglycone form of flavonoid glycosides, which has been used as a nutritional supplement and may be beneficial against a variety of diseases, including cancer [101]. It has been reported that quercetin has a higher reduction potential compared with curcumin, that it reduced LPSinduced ROS/NO production to near normal levels [102]. It has also been reported that long-term exposure of cancer cells to quercetin may prevent cell proliferation and survival, and the interference of quercetin with cellcycle progression diminishes the efficacy of microtubule-targeting drugs such as taxol and nocodazole to arrest cells at G2/M [103].

It has also been revealed that some antioxidants (e.g., quercetin and naringenin) are able to inhibit cytochrome P450 enzymes (CYP1A1 and CYP3A4, respectively) involved in the bioactivation of chemical carcinogens [28], constituting another proposed chemopreventive mechanism of polyphenols against cancer development including lung cancer $[104,105]$.

Preclinical studies have shown that large doses of ascorbic acid (Vitamin C) show significant anticancer effects in animal models and tissue culture investigations [106-108]. These include direct cytotoxic effects in certain cancer cell lines at micromolar $(\mu \mathrm{M})$ to millimolar (mM) concentrations [109]. Early clinical studies suggested that intravenous (i.v.) and oral ascorbic acid may diminish symptoms and possibly prolong survival in terminal cancer patients [110-112].

Other antioxidants such as isoflavones and indole-3-carbinol (I3C), and its in vivo dimeric product 3,3-diindolylmethane (DIM) exhibit a promising effect on the inhibition of ROS accumulation [113-116]. The main sources of isoflavones are soy and other plants in the Legume family and Brassica family. The isoflavones include genistein, daidzein, glycitein, formononetin, biochanin A, desmethylangolensin, and equol. The Brassica family is the main source of I3C and DIM. The isoflavones, I3C and DIM, have been shown to inhibit NF-kB activation stimulated by ROS $[117,118]$ suggesting their potent ability as antioxidants. The inhibition of cancer growth by isoflavones could be mediated through induction of apoptosis and the modulation of expression of the genes related to the cell growth and apoptotic processes [119-123].

\section{RELATION OF ANTIOXIDANT THERAPY WITH OTHER THERAPIES}

A widespread research has been done in the area of cancer prevention and therapeutic and it has been shown that wide range of antioxidants such as glutathione, $\mathrm{N}$-acetylcysteine, coenzyme Q10, lycopene flavonoids, and isoflavones when used in combination with chemotherapy and radiotherapy result in the reduction of drug toxicity and increase the survival time of patients by increasing the tumor response to these therapies [20]. The modulating effects of antioxidants in treatment depend on a wide range of factors, including the metabolic state of the patient, the stage and site of the disease, and the modality being used [124]. The cellular changes would ideally, enhance tumor cell killing, largely by apoptosis, and reduce the probability of normal cell death. Antioxidant enzymes and detoxifiers have the ability to inhibit tumor initiation and promotion in vivo and in vitro [125].

Combinations of antioxidants have been shown synergistic antitumor effects in vivo. Dasari et al. reported that significant upsurge was observed in antioxidant levels between the patients treated with radiotherapy and chemotherapy than the patients treated with chemotherapy alone. Hence, the radiotherapy along with chemotherapy kills and decreases the size of cancer cells which facilitate the significant alterations (increased) in the development of the antioxidant system, which is not possible in case of chemotherapy alone [126]. The efficacy of anticancer drugs used in chemotherapy is limited by the fraction of actively dividing cells because these drugs do not kill resting cells unless those cells divide soon after exposure to the drug. Some of the anticancer drugs including bleomycin, doxorubicin (adriamycin), and cisplatin rely on ROS as they produce free radicals that play a role in treatment [127]. Even when the mechanism of the chemotherapeutic drug is independent of free radical action, antioxidants help to maintain the health of normal tissues and protect them from the toxic effects of free radical producing cytokines that circulate in cancer patients and increase with the severity of the disease [128]. Another therapy, i.e., radiotherapy uses ionizing radiations ( $\mathrm{x}$ - and $\gamma$-rays) to induce cancer cell death through free radical formation. This therapy includes two mechanisms: First mechanism is apoptosis, resulting in cell death within a few hours of radiation and second mechanism is a radiationinduced failure of mitosis and the inhibition of cellular proliferation which kills cancer cells [20]. About two-thirds of $x$ - and $\gamma$-ray damage is caused by free radicals that kill tumor cells but intimidate the reliability and endurance of surrounding normal cells. Response to radiation depends on the type, dosage and time intervals of radiation, inherent tissue sensitivity, and intracellular factors that include position in the cell cycle, concentration of oxygen, thiols, and other antioxidants [85].

\section{CONCLUSION}

The abnormal production of free radicals has been known to cause several human diseases. The antioxidant defense system can only protect the body when the normal physiological level of the free radicals is maintained. When there is a high level of ROS, increasing their burden in the body, it leads to oxidative stress, tissue injury and subsequent diseased conditions. The balance between the two has to be maintained as low antioxidant status lead to enhanced oxidative stress in cancer patients, even before oncology treatment starts. Data from several experiments done both in vivo and in vitro conditions have illustrated the importance of antioxidants in cancer prevention therapies. The combination of radiotherapy and chemotherapy has shown beneficial outputs and has demonstrated the role of enhanced oxidant system. Radiotherapy along with chemotherapy kills and decrease the size of cancer cells which facilitate the significant alterations in the development of the antioxidant system, which is not possible in case of chemotherapy alone. Therefore, the need of the hour is to put more efforts for clinical validation of the promising antioxidant agents. There is a need to prove whether antioxidant therapies can prevent or overcome the damaging effects of ROS in life-threatening situations. The compounds must be tested for their safety, toxicity, selectivity, bioavailability, and therapeutic efficacy. In this context, full execution of clinical trials in well-identified and best-suited populations need to be done to determine the efficacy of antioxidant agents in cancer prevention as well as cancer therapeutics. Combination therapy with these agents can also be tried to achieve synergistic clinical effects.

Newer approaches utilizing collaborative research and modern technology in combination with established traditional health principles will yield dividends in the near future in improving health, especially among those who do not have access to the use of costlier western systems of medicine, thus decreasing death rates.

\section{CONFLICTS OF INTEREST}

The authors have declared no conflicts of interest.

\section{ACKNOWLEDGEMENTS}

RVS is supported by "Pilot Project grant for Young Investigators in Cancer Biology," Department of Biotechnology, Government of India (BT/PR9613/MED/30/1260/2013). AKS is supported by Indo- 
New Zealand grant by the Department of Science and Technology, Government of India (INT/NZ/P-001/2013).

\section{REFERENCES}

1. Gilbert DL. Oxygen and Living Processes: An Interdisciplinary Approach. New York: Springer; 1981.

2. Sireesha K, Rao SP. Oxidative stress and diabetes: An overview. Asian J Pharm Clin Res 2015;8:15-19.

3. Weidinger A, Kozlov AV. Biological activities of reactive oxygen and nitrogen species: Oxidative stress versus signal transduction. Biomolecules 2015;5:472-84.

4. Halliwell B. Free radicals, antioxidants, and human disease: Curiosity, cause, or consequence. Lancet 1994;344:721-724.

5. Yoshikawa T, Toyokuni S, Yamamoto Y, Naito Y. Free Radicals in Chemistry Biology and Medicine. London: OICA International; 2000.

6. Valko M, Izakovic M, Mazur M, Rhodes CJ, Telser J. Role of oxygen radicals in DNA damage and cancer incidence. Mol Cell Biochem 2004;266:37-56.

7. Inoue M, Sato EF, Nishikawa M, Park AM, Kira Y, Imada I, et al. Mitochondrial generation of reactive oxygen species and its role in aerobic life. Curr Med Chem 2003;10:2495-505.

8. Cadenas E, Davies KJA. Mitochondrial free radical generation, oxidative stress, and aging. Free Rad Biol Med 2000;29:222-230.

9. Dupont GP, Huecksteadt TP, Marshall BC, Ryan US, Michael JR, Hoidal JR, et al. Regulation of xanthine dehydrogenase and xanthine oxidase activity and gene expression in cultured rat pulmonary endothelial cells. J Clin Invest 1992;89:197-202.

10. Shah K, Kumar RG, Verma S, Dubey RS. Effect of cadmium on lipid peroxidation, superoxide anion generationand activities of antioxidant enzymes in growing rice seedlings. Plant Sci 2001;6:1135-44.

11. Mittler R. Oxidative stress, antioxidants and stress tolerance. Trends Plant Sci 2002;7:405-10.

12. Harman D. Ageing: A theory based on free radical and radiation chemistry. J Gerontol 1958;11:298-300.

13. Halliwell B, Gutteridge JM. Free Radicals in Biology and Medicine. Oxford: Oxford University Press; 1997.

14. Datta K, Sinha S, Chattopadhyay P. Reactive oxygen species in health and disease. Natl Med J India 2000;13:304-10.

15. Faraci FM, Didion SP. Vascular protection: Superoxide dismutase isoforms in the vessel wall. Arterioscler Thromb Vasc Biol 2004; $24: 1367-73$.

16. Schafer FQ, Buettner GR. Redox environment of the cell as viewed through the redox state of the glutathione disulfi de/glutathione couple. Free Radic Biol Med 2001;30:1191-336.

17. Lander HM. An essential role for free radicals and derived species in signal transduction. FASEB J 1997;11:118-24.

18. Johnson IT, Williamson G, Musk SR. Anti carcinogenic factors in plant foods: A new class of nutrients? Nutr Res Rev 1994;7:175-204.

19. Mates JM, Gomez PC, De Castro IN. Antioxidant enzymes and human diseases. Clin Biochem 1999;32:595-603

20. Lamson DW, Brignall MS. Antioxidants in cancer therapy; Their actions and interactions with oncologic therapies. Altern Med Rev 1999;4:304-29

21. Prasad KN, Cole WC, Kumar B, Prasad KC. Scientific rationale for using high-dose multiple micronutrients as an adjunct to standard and experimental cancer therapies. J Am Coll Nutr 2001;20:450S-463S.

22. Forman HJ, Fukuto JM, Miller T, Zhang H, Rinna A, Levy S, et al. The chemistry of cell signaling by reactive oxygen and nitrogen species and 4-hydroxynonenal. Arch Biochem Biophys 2008;477:183-95.

23. Alexandre J, Trachootham D, Huang P. Targeting cancer cells by ROSmediated mechanisms: A radical therapeutic approach? Nat Rev Drug Discov 2009;8:579-91.

24. Stief TW. The physiology and pharmacology of singlet oxygen. Med Hypotheses 2003;60:567-72.

25. Palmer RM, Rees DD, Ashton DS, Moncada S. L-arginine is the physiological precursor for the formation of nitric oxide in endothelium-dependent relaxation. Biochem Biophys Res Commun 1988; $153: 1251-6$

26. Halliwell B. Antioxidants and human disease: A general introduction. Nutr Rev 1997;55:S44-9.

27. Miljkovic D, Trajkovic V. Inducible nitric oxide synthase activation by interleukin-17. Cytokine Growth Factor Rev 2004;15:21-32.

28. Obermeier MT, White RE, Yang CS. Effects of bioflavonoids on hepatic P450 activities. Xenobiotica 1995;25:575-84

29. McMillan K, Bredt DS, Hirsch DJ, Snyder SH, Clark JE, Masters BS, et al. Cloned, expressed rat cerebellar nitric oxide synthase contains stoichiometric amounts of heme, which binds carbon monoxide. Proc Natl Acad Sci U S A 1992;89:11141-5.

30. Park JS, Jung JS, Jeong YH, Hyun JW, Le TK, Kim DH, et al. Antioxidant mechanism of isoflavone metabolites in hydrogen peroxide-stimulated rat primary astrocytes: Critical role of hemeoxygenase-1 and NQO1 expression. J Neurochem 2011;119:909-19.

31. Carr AC, McCall MR, Frei B. Oxidation of LDL by myeloperoxidase and reactive nitrogen species: Reaction pathways and antioxidant protection. Arterioscler Thromb Vasc Biol 2000;20:1716-23.

32. Stamler JS, Jaraki O, Osborne J, Simon DI, Keaney J, Vita J, et al. Nitric oxide circulates in mammalian plasma primarily as an S-nitroso adduct of serum albumin. Proc Natl Acad Sci U S A 1992;89:7674-7.

33. Bravo L. Polyphenols: Chemistry, dietary sources, metabolism, and nutritional significance. Nutr Rev 1998;56:317-33.

34. Lomaestro BM, Malone M. Glutathione in health and disease: Pharmacotherapeutic issues. Ann Pharmacother 1995;29:1263-73.

35. Leonard SS, Harris GK, Shi XL. Metal-induced oxidative stress and signal transduction. Free Radic Biol Med 2004;37:1921-42.

36. Ercal N, Orhan GH, Burns AY. Toxic metals and oxidative stress Part 1: Mechanisms involved in metal induced oxidative damage. Curr Top Med Chem 2001;1:529-539.

37. Stepnik M, Stanczyk M, Arkusz J, Lewinska D. Assessment of apoptosis in thymocytes and splenocytes from mice exposed to arsenate in drinking water: Cytotoxic effects of arsenate on the cells in vitro. J Environ Sci Health Tox Hazard Subst Environ Eng 2005;40:369-384.

38. Sharma A, Sharma MK, Kumar M. Modulatory role of Emblica officinalis fruit extract against arsenic induced oxidative stress in Swiss albino mice. Chem Biol Interact 2009;180:20-30.

39. Gupta R, Flora SJ. Effect of Centella asiatica on arsenic induced oxidative stress and metal distribution in rats. J Appl Toxicol 2006;26:213-222.

40. Cuypers A, Vangronsveld J, Clijsters H. The chemical behaviors of heavy metals play prominent role in the induction of oxidative stress. Free Radic Res 199;31:39-43.

41. Rice-Evans CA, Diplock AT. Current status of antioxidant therapy. Free Radic Biol Med 1993;15:77-96.

42. Krinsky NI. Mechanism of action of biological antioxidants. Proc Soc Exp Biol Med 1992;200:248-254

43. Bredt DS, Snyder SH. Isolation of nitric oxide synthetase, a calmodulinrequiring enzyme. Proc Natl Acad Sci U S A 1990;87:682-5

44. Amir Aslani B, Ghobadi S. Studies on oxidants and antioxidants with a brief glance at their relevance to the immune system. Life Sci 2016;146:163-73.

45. Rahman K. Studies on free radicals, antioxidants, and co-factors. Clin Interv Aging 2007:2:219-36.

46. Valko M, Rhodes CJ, Moncol J, Izakovic M, Mazur M. Free radicals, metals and antioxidants in oxidative stress-induced cancer. Chem Biol Interact 2006;160:1-40.

47. Dickinson DA, Forman HJ. Cellular glutathione and thiols metabolism. Biochem Pharmacol 2002;64:1019-26.

48. Gathwala G, Aggarwal R. Selenium supplementation for the pre-term Indian neonate. Indian J Public Health 2016;60:142-144.

49. Forsberg L, de Faire U, Morgenstern R. Oxidative stress, human genetic variation, and disease. Arch Biochem Biophys 2001;389:84-93.

50. Jan AT, Azam M, Siddiqui K, Ali A, Choi I, Haq QM, et al. Heavy metals and human health: Mechanistic insight into toxicity and counter defense system of antioxidants. Int J Mol Sci 2015;16:29592-630.

51. Young IS, Woodside JV. Antioxidants in health and disease. J Clin Pathol 2001:54:176-86.

52. Halliwell B, Gutteridge JM. Free Radicals in Biology and Medicine. $5^{\text {th }}$ ed. Oxford: Oxford University Press; 2005. p. 753.

53. Duggett NA, Griffiths LA, McKenna OE, de Santis V, Yongsanguanchai N, Mokori EB, et al. Oxidative stress in the development, maintenance and resolution of paclitaxel-induced painful neuropathy. Neuroscience 2016;333:13-26.

54. Yang WS, Stockwell BR. Synthetic lethal screening identifies compounds activating iron-dependent, nonapoptotic cell death in oncogenic-RAS-harboring cancer cell. Chem Biol 2008;15:234-45.

55. Cao JY, Dixon SJ. Mechanisms of ferroptosis. Cell Mol Life Sci 2016;73:2195-209.

56. Yang WS, SriRamaratnam R, Welsch ME, Shimada K, Skouta R, Viswanathan VS, et al. Regulation of ferroptotic cancer cell death by GPX4. Cell 2014;156:317-31.

57. Seiler A, Schneider M, Förster H, Roth S, Wirth EK, Culmsee C, et al. Glutathione peroxidase 4 senses and translates oxidative stress into 12/15-lipoxygenase dependent- and AIF-mediated cell death. Cell Metab 2008;8:237-48 
58. Wang W, Xia MX, Chen J, Yuan R, Deng FN, Shen FF. Gene expression characteristics and regulation mechanisms of superoxide dismutase and its physiological roles in plants under stress. Biochemistry 2016;81:465-480.

59. Noor R, Mittal S, Iqbal J. Superoxide dismutase - Applications and relevance to human diseases. Med Sci Monit 2002;8:RA210-5.

60. Guo Z, Boekhoudt GH, Boss JM. Role of the intronic enhancer in tumor necrosis factor-mediated induction of manganous superoxide dismutase. J Biol Chem 2003;278:23570-8

61. Borras C, Gambini J, Cabrera GM, Sastre J, Pallardo FV, Mann GE, et al. 17beta-oestradiol up-regulates longevity related, antioxidant enzyme expression via the ERK1 and ERK2 [MAPK]/NF kappa B cascade. Aging Cell 2005;4:113-118.

62. Pourvali K, Abbasi M, Mottaghi A. Role of superoxide dismutase 2 gene ala16Val polymorphism and total antioxidant capacity in diabetes and its complications. Avicenna J Med Biotechnol 2016;8:48-56.

63. Sjoquist PO, Marklund SL. Endothelium bound extracellular superoxide dismutase type $\mathrm{C}$ reduces damage in reperfuse dischaemic rat hearts. Cardiovasc Res 1992;26:347-50.

64. Leite PF, Danilovic A, Moriel P, Dantas K, Marklund S, Dantas AP, et al. Sustained decrease in superoxide dismutase activity underlies constrictive remodeling after balloon injury in rabbits. Arterioscler Thromb Vasc Biol 2003;23:2197-202.

65. Youn HD, Kim EJ, Roe JH, Hah YC, Kang SO. A novel nickelcontaining superoxide dismutase from Streptomyces spp. Biochem J 1996;318:889-896.

66. Schmidt A, Gube M, Schmidt A, Kothe E. In silico analysis of nickel containing superoxide dismutase evolution and regulation. J Basic Microbiol 2009;49:109-18.

67. Ayeleso A, Brooks N, Oguntibeju O. Modulation of antioxidant status in streptozotocin-induced diabetic male wistar rats following intake of red palm oil and/or rooibos. Asian Pac J Trop Med 2014;7:536-44

68. Edem DO. Haematological and histological alterations induced in rats by palm oil-containing diets. Eur J Sci Res 2009;32:405-518.

69. Iswaldi I, Arráez-Román D, Rodríguez-Medina I, Beltrán-Debón R, Joven J, Segura-Carretero A, et al. Identification of phenolic compounds in aqueous and ethanolic rooibos extracts (Aspalathus linearis) by HPLC-ESI-MS (TOF/IT). Anal Bioanal Chem 2011;400:3643-54.

70. Masella R, Di Benedetto R, Vari R. Novel mechanisms of natural antioxidant compounds in biological systems: involvement of glutathione and glutathione-related enzymes. J Nutr Biochem 2005; $16: 577-86$.

71. Ames BN, Shigenaga MK. Oxidants are a major contributor to aging. Ann N Y Acad Sci 1992;663:85-96.

72. Ames BN, Shigenaga MK, Hagen TM. Oxidants, antioxidants and degenerative diseases of aging. Proc Natl Acad Sci 1993;90:7915-22.

73. Zhou Y, Lee AS. Mechanism for the suppression of the mammalian stress response by genistein, an anticancer phytoestrogen from soy. J Natl Cancer Inst 1998;90:381-8.

74. Halliwell B, Aruoma OI. DNA and Free Radicals. Boca Raton: CRC Press; 1993.

75. Gupta S. Molecular steps of TNF receptor-mediated apoptosis. Curr Mol Med 2001;1:299-306.

76. Szatrowski TP, Nathan CF. Production of large amounts of hydrogen peroxide by human tumor cells. Cancer Res 1991;51:794-8.

77. Kawanishi S, Hiraku Y, Pinlaor S, Ma N. Oxidative and nitrative DNA damage in animals and patients with inflammatory diseases in relation to inflammation-related carcinogenesis. Biol Chem 2006;387:365-72.

78. Seifirad S, Keshavarz A, Taslimi S, Aran S, Abbasi H, Ghaffari A, et al. Effect of pirfenidone on pulmonary fibrosis due to paraquat poisoning in rats. Clin Toxicol (Phila) 2012:50:754-8.

79. Lu LY, Ou N, Lu QB. Antioxidant induces DNA damage, cell death and mutagenicity in human lung and skin normal cells. Sci Rep 2013;3:3169

80. Seifirad S, Masoudkabir F. Apelin could reduce risk of contrast-induced nephropathy in patients with congestive heart failure. Med Hypotheses 2013;81:898-900

81. Weel EA, Redekop WK, Weening RS. Increased risk of malignancy for patients with chronic granulomatous disease and its possible link to the pathogenesis of cancer. Eur J Cancer 1996;32A:734-5.

82. Irani K, Xia Y, Zweier JL, Sollott SJ, Der CJ, Fearon ER, et al. Mitogenic signaling mediated by oxidants in ras-transformed fibroblasts. Science 1997;275:1649-52

83. Rodrigues MS, Reddy MM, Sattler M. Cell cycle regulation by oncogenic tyrosine kinases in myeloid neoplasias: From molecular redox mechanisms to health implications. Antioxid Redox Signal 2008;10:1813-48.
84. Brandon M, Baldi P, Wallace DC. Mitochondrial mutations in cancer. Oncogene 2006;25:4647-62.

85. Coia LR, Moyland DJ. Introduction to Clinical Radiation Oncology. Madison, WI: Medical Physics Publishing; 1998. p. 15-9.

86. Galadari S, Rahman A, Pallichankandy S, Thayyullathil F. Reactive oxygen species and cancer paradox: To promote or to suppress? Free Radic Biol Med 2017;104:144-64.

87. Muthukkaruppan VR, Kubai L, Auerbach R. Tumor-induced neovascularization in the mouse eye. J Natl Cancer Inst 1982;69:699-708.

88. Potente M, Gerhardt H, Carmeliet P. Basic and therapeutic aspects of angiogenesis. Cell 2011;146:873-87.

89. Nussbaumer S, Bonnabry P, Veuthey JL, Fleury-Souverain S. Analysis of anticancer drugs: A review. Talanta 2011;85:2265-89.

90. Gupta M, Dahiya J, Marwaha RK, Dureja H. Therapies in Cancer treatment: An overview. Int J Pharm Pharm Sci 2015;7:1-9.

91. Monsuez JJ, Charniot JC, Vignat N, Artigou JY. Cardiac side-effects of cancer chemotherapy. Int J Cardiol 2010;144:3-15.

92. Dropcho EJ. The neurologic side effects of chemotherapeutic agents. Continuum (Minneap Minn) 2011;17:95-112.

93. Kasapović J, Pejić S, Todorović A, Stojiljković V, Pajović SB. Antioxidant status and lipid peroxidation in the blood of breast cancer patients of different ages. Cell Biochem Funct 2008;26:723-30.

94. Martin RC, Liu Q, Wo JM, Ray MB, Li Y. Chemoprevention of carcinogenic progression to esophageal adenocarcinoma by the manganese superoxide dismutase supplementation. Clin Cancer Res 2007; 13:5176-82.

95. Fu TY, Hou YY, Chu ST, Liu CF, Huang CH, Chen HC, et al. Manganese superoxide dismutase and glutathione peroxidase as prognostic markers in patients with buccal mucosal squamous cell carcinomas. Head Neck 2011;33:1606-15.

96. Chung-man Ho J, Zheng S, Comhair SA, Farver C, Erzurum SC. Differential expression of manganese superoxide dismutase and catalase in lung cancer. Cancer Res 2001;61:8578-85.

97. Surapaneni KM, Sadagopan C. Status of lipid peroxidation and antioxidant enzymes in patients with carcinoma of breast. J Med Sci Res 2007;1:21-4.

98. Moscow JA, Schmidt L, Ingram DT, Gnarra J, Johnson B, Cowan $\mathrm{KH}$, et al. Loss of heterozygosity of the human cytosolic glutathione peroxidase I gene in lung cancer. Carcinogenesis 1994; $15: 2769-73$

99. Ratnasinghe D, Tangrea JA, Andersen MR, Barrett MJ, Virtamo J, Taylor PR, et al. Glutathione peroxidase codon 198 polymorphism variant increases lung cancer risk. Cancer Res 2000;60:6381-3.

100. Tripathi P, Singh A. Natural resources from plants in the treatment of cancer: An update. Asian J Pharm Clin Res 2017;10:13-22.

101. Neuhouser ML. Dietary flavonoids and cancer risk: Evidence from human population studies. Nutr Cancer 2004;50:1-7.

102. Zhang M, Swarts SG, Yin L, Liu C, Tian Y, Cao Y, et al. Antioxidant properties of quercetin. Adv Exp Med Biol 2011;701:283-9.

103. Samuel T, Fadlalla K, Turner T, Yehualaeshet TE. The flavonoid Quercetin transiently inhibits the activity of Taxol and nocodazole through interference with the cell cycle. Nutr Cancer 2010;62:1025-35.

104. Le Marchand L, Murphy SP, Hankin JH, Wilkens LR, Kolonel LN. Intake of flavonoids and lung cancer. J Natl Cancer Inst 2000;92:154-60.

105. Thakur RS, Ahirwar B. Evaluation of medicinal plants for cytotoxicity against various cancer cell lines. Int J Pharm Pharm Sci 2017;9:198-202.

106. Bram S, Froussard P, Guichard M, Jasmin C, Augery Y, Sinoussi-Barre F, et al. Vitamin C preferential toxicity for malignant melanoma cells. Nature 1980;284:629-31.

107. Farooqui M, Pardeshi R, Jadhav S. Antioxidant-vitamin C: Lung function; Lung cancer. Asian J Pharm Clin Res 2016;9:43-51.

108. Chen Q, Espey MG, Krishna MC, Mitchell JB, Corpe CP, Buettner GR, et al. Pharmacologic ascorbic acid concentrations selectively kill cancer cells: Action as a pro-drug to deliver hydrogen peroxide to tissues. Proc Natl Acad Sci U S A 2005;102:13604-9.

109. Leung PY, Miyashita K, Young M, Tsao CS. Cytotoxic effect of ascorbate and its derivatives on cultured malignant and nonmalignant cell lines. Anticancer Res 1993;13:475-80.

110.Cameron E, Pauling L. The orthomolecular treatment of cancer. I. The role of ascorbic acid in host resistance. Chem Biol Interact 1974;9:273-83

111. Cameron E, Pauling L. Supplemental ascorbate in the supportive treatment of cancer: Prolongation of survival times in terminal human cancer. Proc Natl Acad Sci U S A 1976;73:3685-9.

112.Padayatty SJ, Riordan HD, Hewitt SM, Katz A, Hoffer LJ, Levine M, et al. Intravenously administered vitamin $\mathrm{C}$ as cancer therapy: Three cases. CMAJ 2006; 174:937-42. 
113.Benabadji SH, Wen R, Zheng JB, Dong XC, Yuan SG. Anticarcinogenic and antioxidant activity of diindolylmethane derivatives. Acta Pharmacol Sin 2004;25:666-71.

114.Exner M, Hermann M, Hofbauer R, Kapiotis S, Quehenberger P, Speiser W, et al. Genistein prevents the glucose autoxidation mediated atherogenic modification of low density lipoprotein. Free Radic Res 2001;34:101-12.

115.Fan S, Meng Q, Saha T, Sarkar FH, Rosen EM. Low concentrations of diindolylmethane, a metabolite of indole-3-carbinol, protect against oxidative stress in a BRCA1-dependent manner. Cancer Res 2009;69:6083-91.

116. Patel RP, Boersma BJ, Crawford JH, Hogg N, Kirk M, Kalyanaraman B, et al. Antioxidant mechanisms of isoflavones in lipid systems: Paradoxical effects of peroxyl radical scavenging. Free Radic Biol Med 2001;31:1570-81.

117.Chinni SR, Li Y, Upadhyay S, Koppolu PK, Sarkar FH. Indole-3carbinol (I3C) induced cell growth inhibition, G1 cell cycle arrest and apoptosis in prostate cancer cells. Oncogene 2001;20:2927-36.

118. Davis JN, Kucuk O, Djuric Z, Sarkar FH. Soy isoflavone supplementation in healthy men prevents NF-kappa B activation by TNF-alpha in blood lymphocytes. Free Radic Biol Med 2001;30:1293-302.

119. Alhasan SA, Pietrasczkiwicz H, Alonso MD, Ensley J, Sarkar FH. Genistein-induced cell cycle arrest and apoptosis in a head and neck squamous cell carcinoma cell line. Nutr Cancer 1999;34:12-9.

120. Li Y, Bhuiyan M, Sarkar FH. Induction of apoptosis and inhibition of c-erbB-2 in MDA-MB-435 cells by genistein. Int $\mathrm{J}$ Oncol 1999; $15: 525-33$

121. Li Y, Ahmed F, Ali S, Philip PA, Kucuk O, Sarkar FH, et al. Inactivation of nuclear factor kappaB by soy isoflavone genistein contributes to increased apoptosis induced by chemotherapeutic agents in human cancer cells. Cancer Res 2005;65:6934-42.

122. Lian F, Bhuiyan M, Li YW, Wall N, Kraut M, Sarkar FH, et al. Genistein-induced G2-M arrest, p21WAF1 upregulation, and apoptosis in a non-small-cell lung cancer cell line. Nutr Cancer 1998;31:184-91.

123. Zhou BB, Elledge SJ. The DNA damage response: Putting checkpoints in perspective. Nature 2000;408:433-9.

124. VandeCreek L, Rogers E, Lester J. Use of alternative therapies among breast cancer outpatients compared with the general population. Altern Ther Health Med 1999;5:71-6.

125. Oberley TD, Oberley LW. Antioxidant enzyme levels in cancer. Histol Histopathol 1997;12:525-35.

126. Dasari S, Wudayagiri R, Valluru L. Efficacy of treatment on antioxidant status in cervical cancer patients: A case control study. Free Radic Antioxid 2013;3:87-92.

127. Borek C. Dietary antioxidants and human cancer. Integr Cancer Ther 2004;3:333-41

128. Sözen S, Coskun U, Sancak B, Bukan N, Günel N, Tunc L, et al. Serum levels of interleukin-18 and nitrite+nitrate in renal cell carcinoma patients with different tumor stage and grade. Neoplasma 2004;51:25-9. 